\title{
TOWARDS ADEQUATE DEFENCE OF HUMAN RIGHTS IN AFRICA
}

\author{
By Emmanuel Oмон Esiemokhai
}

Among the decisions taken by African Heads of State during their Summit Meeting in Monrovia in July, 1979, the decision to create an African Human Rights defence mechanism was very significant. African Heads of State spoke out in unison and expressed concern over violations of human rights and stated that these have become a disturbing feature in the continent. Although diplomatic etiquette did not permit name calling, it was obvious that they clearly had in mind Equatorial Guinea under the late Marcias Nguema, Uganda, under Amin and the defunct Central African Empire under Jean Bokassa. Although violations of human rights are not entirely new in Africa, it is remarkable that concern was recently demonstrated by African leaders in a collective manner. This seemed to suggest that the problem had reached intolerable proportions. The collective response also indicates that there is better information about events in African states which helps to ignite popular outrage against violations of human rights.

It is perhaps pertinent to illustrate cases of violations of human rights in some African countries. When the first president of Algeria, Ahmed Ben Bella, was over-thrown in the early 60 's in a coup d'état, the new Government headed by late Houary Boumediene, kept Ben Bella in prison custody, without due process of trial, for over a decade. Secondly, Nigerian labourers who worked in the plantations of Equatorial Guinea, were subjected to forced labour and inhuman treatment by the regime of the late President of Equatorial Guinea, Marcias Nguema. Labourers who wished to leave the farms were held against their wish. This violates the right of freedom of movement. The Nigerian Government had to repatriate them in 1975. Thirdly, the Ethiopian military operation in Eritrea, has forced some Eritrean nationals into exile, while others have fled to neighbouring countries, where they live as refugees. Fourthly, the recent troubles in Chad between the various factions precipated a situation, in which people were arbitrarily arrested and detained.

The subject of respect of human rights has gained unprecedented popularity in the last ten years in the whole world. This is partly because of the success of the process of decolonisation and the struggle against colonialism, racism and injustice on a world-wide scale. Also more information is now available on disrespect for human rights in most undemocratic states. Contemporary history is full of the horrors of facism, apartheid, colonialism and racial discrimination.

\section{Euro-American Human Rights Institutions}

Since the establishement of the United Nations Organisation, concrete rules of international law with regards to protection of human rights against violations by States have been formulated. Other regional international organisations like the Council of Europe, the Organisation of American States, have transformed generally proclaimed philosophical principles into enforceable legal obligations for member states thereby setting an invaluable legal precedent which other regional international organisations might eventually adopt.

The Council of Europe adopted the Convention for the Protection of Human Rights which was signed in Rome, on November 4, 1950. The Convention came into force on September 3rd, 1953. It has long been ratified by all member states of the Council of Europe. Also, the 
Organisation of American States adopted the American Human Rights Convention in 1969. The Council of Europe has not only adopted a Convention on Human Rights but went on to establish a Commission and Court of Human Rights in Strasbourg. The Council has also set up elaborate procedures within both the Commission and the Court of Human Rights to ensure adequate realisation of the rights guaranteed in the European Convention of Human Rights of 1953. A concrete proof of the workability of the system is reflected in the number of cases that have been referred to the European Commission and the Court of Human Rights since their establishment. These efforts show how high the idea of human rights has gained in juridicial considerations. It is in this light that one welcomes the decision of African Heads of States to establish an African Court of Human Rights.

\section{Human Rights in Africa}

A review of the practice of African nations in the field of human rights is not flattering. During colonialism, it was European colonizers who violated human rights in their efforts to enforce the political and legal authority of the Colonial Government and ensure smooth colonial administration. One would have thought that when African States gained their independence the unpleasant experiences of the repressive colonial regimes would have made their leaders to abhor violations of human rights. Instead, some African leaders showed traits of intolerance, highhandedness and callousness in dealing with political opponents and nonconformists.

When the colonies of Britain and the Netherland gained independence, detailed provisions for protection of human rights were entrenched in their constitutions. However, as some African states proceeded with self-government after independence, their national leaders allowed political considerations to affect the level of human values which, in many African States, have progressively become obscured in a maelstrom of political colloquy.

In the African continent, the rule of law has been shaken to the marrow. The bare bones of fundamental human rights have been laid bare to ridicule ${ }^{\mathbf{1}}$.

In some African States today, there exist one party governments, military juntas, and authoritarian presidential regimes. Political stability, where it exists, is attributable more or less, to indefinite periods of emergency regulations. Also it would be traceable to political lethargy of the governed caused either by illiteracy or just resignation. In authoritarian presidential regimes, stability may be credit to presidential high-handedness, political intrigue and intimidation which are geared towards the liquidation of political opposition. Anyone who dares question the right of the president to rule indefinitely ${ }^{2}$, could be likened to someone swimming in a crocodile infested river. Nevertheless, people agitate as the level of their consciousness of these violations rises.

In benevolent military regimes, and one party states, members of the legal profession have long since known that only if they do not actively engage in legal or political protestations, will the independence of the judiciary continue to be guaranteed. In Nigeria, for example, decrees under military rule, constituted the supreme law. Each of the military revolution of January 15, 1966, July 29, 1966 and July 1975, removed the pre-existing legal order ${ }^{3}$. Any part of the constitution of the Federal or of the constitution of the former regions that re-

\footnotetext{
1 E. O. Esiemokhai, "The Rule of Law in Africa", Nigerian Tribune, May 9, 1975, p.4.

2 Ugandan dictator, Idi Amin, authoritarian, Equatorial Guinea President late Marcias Nguema and the deposed Emperor Jean Bokassa of the Central African Empire declared themselves "Presidents for Life".

3 A. Obilade, The Nigerian Legal System, Sweet and Maxwell, 1979, p. 46.
} 
mained in force applied only by virtue of a Decree 4 . In the rare case of display of guts the Federal Nigerian Supreme Court held in Lakanmi v. Attorney-General (West) ${ }^{5}$ case that a Decree was void notwithstanding the provisions of section 6 of the Constitution (Suspension and Modification) Decree 1966, which provided that no question as to the validity of a Decree was to be entertained by a court of law. To show military intolerance towards this $\mathrm{Su}$ preme Court ruling, the Federal Military regime passed a new Decree, Federal Military Government (Supreme and Enforcement of Powers) Decree 19706. It was made to correct the legal position stated in the Lakanmi case. While the new decree still recognised the Supreme Court as the Highest court in Nigeria, its powers were considerably weakened. The appointment of the Chief Justice of Nigeria became the sole responsibility of the Head of the Federal Military Government.

In some African Countries, the fourth estate of the realm (the press) has become used to rigorous self-censorship, otherwise editors 'may publish and be damned'. Speaking to the Royal African Society in London, the experienced Nigerian journalist, Alhaji Babatunde Jose, former Chairman of the Daily Times of Nigeria said that "an apparently innocuous report or investigation that an American editor would use without hesitation, could in Africa, earn the editor a period in jail. It would even, in certain omnious stance be that editor's last." From the above review of the position of respect of human rights in Africa, one can safely say that the precarious position of judges, journalists and critics in Africa affords a sad commentary on the rule of law in the continent ${ }^{7}$. These negative developments and human rights violations have led to calls ${ }^{8}$ for an African Court of Human Rights where States which fail to uphold fundamental human rights in the continent could be exposed. For example, the existence of the European Court of Human Rights, encouraged Greek nationals, to expose anti-democratic occurences in Greece during the reign of the military junta. This led to the demand in Europe and America for the return of democracy in Greece.

It is amazing that African leaders used the political slogan, "Respect for human dignity" to whip up support during the struggle for independence but have not fared better when they took over. There are many prisoners of conscience today in many African States ${ }^{9}$. Any state which tramples on human rights and raised the practice to the level of official policy must be roundly condemned.

\section{Human Rights at the United Nations}

Apartheid is not only an intolerable policy, it is manifestly inhuman. Its roots are firmly anchored in a weird political system which refuses to grant equal rights and equal opportunities to all races living in its territory. Preferential treatment is given to white settlers based only on the colour of their skins, which in the author's view, is wrong. Man should be evaluated according to his contribution to societal progress and well being.

Humanists, jurists and statesmen have unleashed concerted action against apartheid. Progressive white people have also been engaged in the struggle against the system. In the van- 
guard against this struggle, stood Mahatma Gandhi. In 1946, the Government of India complained to the United Nations about the racial discrimination against people of Indian origin in South Africa.

\section{United Nations and Apartheid}

As far back as 1948, the United Nations adopted the Universal Declaration of Human Rights. Although this declaration was not very precise, yet it formed the international legal basis for the struggle against violations of human rights by oppressive regimes the world over. As Ian Brownlie put it, the references to human rights in the Charter of the United Nations have provided the basis for elaboration of the content of standards and of the machinery for implementing protection of human rights ${ }^{10}$. The Universal Declaration of Human Rights of 1948 reflected in the main, a determination by the international community to avoid "contempt for human rights ${ }^{11}$ " which resulted in barbarous acts during the second World War and which "outraged the conscience of mankind ${ }^{12}$ ". The aim of its authors was to ensure that human rights should be protected by the rule of law.

In 1965, the United Nations adopted a declaration against all forms of racial discrimination and the same year witnessed the coming into being of the International Convention on the Elimination of all Forms of Racial Discrimination. These legal actions concretised the vague clauses on the subject in the Universal Declaration of Human Rights.

Members of the Organisation of African Unity have been vocal at the United Nations and have always been supported by the Governments of India and the Soviet Union during the passage of - (a) United Nations General Assembly Resolution 3411D (XXX) in 1975 and (b) The United Nations Security Council's unanimous imposition of an embargo against apartheid South Africa. As a result of these advances in the struggle for human rights in Africa, one can now discuss the proposed establisment of an African Defence Mechanism for $\mathrm{Hu}-$ man Rights.

The struggle for the defence of human rights has a long history. It dominated European legal and political thought throughout the 17 th and 18 th centuries. Human beings were believed to possess certain rights which were fundamental and unchallengable. These were thought to have been derived from some natural law that ruled the universe ${ }^{\mathbf{1 3}}$.

The French jurist Bodin, believed that the act of the sovereign must be bound in his relations to his subjects by the laws of God and Nature. Locke attempted in his writings to enumerate certain natural rights, like the right to live, the right to individual liberty, the right to own property, which rulers bound by natural law should recognise. Human Rights received legal sanctification in the Declaration of Human Rights, which the French Revolutionaries introduced after deposing their King.

As fundamental principles, they held that men were born free and equal in rights, and that the purpose of political association was the confirmation of the natural and alienable rights of man. They stressed in particular, freedom of the press, of religion and from arbitrary arrest. All these have found their way into all constitutions of civilised nations as well as all human rights conventions concluded within the last fifty years in Europe and America.

10 Ian Brownlie, Basic Documents in International Law, Oxford 1967, p. 132.

11 Ibid.

12 Ibid.

13 E. O. Esiemokhai, ,The Organisation of African Unity and the Council of Europe, unpublished Ph. D. Thesis, University of Cologne, 1971, p. 74. 


\section{Propositions for an African Convention on Human Rights}

African drafters of a Convention on Human Rights have the good fortune that they can draw inspiration from both the European Convention on Human Rights (1953) and the more precise American Convention on Human Rights (1969).

Undoubtedly, an African Convention ought to contain a comprehensive list of civil, economic, political, social and cultural rights. We caution that only realisable rights should be guaranted. It would serve very little purpose if elaborate and high-sounding legal rights are advocated which cannot be realised because of the poor state of the national economy. Some problems may arise if citizens are left with unfulfilled hopes raised by conventional treaties to which their governments are signatories. It was perhaps to avoid this that led the United States to refrain from signing the International Convenant on Economic, Social an Cultural Rights of 1966 as well as the International Convenant on Civil and Political Rights of the same year. These convenants and the "Optional Protocol" to the latter convenants have come to be known as the International Bill of Human Right. The Convenants require signatories to recognise or protect a wide range of human rights. The proposed African Convention must comprise all the carefully worked out principles, norms and rights to be found in these documents on Human Rights.

In contemporary international law, the position of the individual has remained controversial. In recent times however, more bold attempts are being made to raise the status of man in international legal considerations. It is suggested that the African Human Rights Convention be modelled along the European system. This is because of the fact that the legal systems that operate in most African nations have their roots in Europe. The Common Law and Droit Civil are widely used in ex-colonies, their attempts at evolving new systems notwithstanding. Although African nations were not direct members of the Council of Europe and signatories to the European Convention on Human Rights, Article 63 of the Convention made its application to the former colonies, dependent on a special declaration by the Colonial Government concerned.

The mechanism for the defence of human rights in Africa should be precise and be well mapped out. There should be An African Commission for Human Rights which should have competence "to receive and consider communication from individuals subject to its jurisdiction, who claim to be victims of violation by that state party of any other rights set forth in the Convenant ${ }^{14}$," although no communication shall be received by the Committee if it concerns a State which is not a party to the Convention.

It is also suggested that member States can take up the genuine and provable cases of violations on behalf of citizens of member states. This is because under traditional international law, the individual has no locus standi, on the theory that his rights will be championed successfully, when dealing with a subject of international law. For example, the Greek government took the United Kingdom to task in connection with the violation of human rights in Cyprus, when the latter was a British Colony. Again, in the Austrian application against Italy, Austria referred to the European Commission on Human Rights, a case involving six young German speaking Italian nationals, from the region of Upper Adige, South Tyrol.

14 See Article 63 of the European Convention on Human Rights, 1950. Article 1. 


\section{Suggested Composition and Procedure}

The Commission should be made up of as many members as there are high contracting parties. Members of the Commission should sit in their individual capacity and not be answerable to their countries or their electors. They should be elected by the Council of Ministers of the OAU from a list of names prepared by the Secretary-General of the Organisation of African Unity on an equitable geographical basis. The Committee should be made up of eminent African jurists, who have distinguished themselves in various fields. The proposed Human Rights Committee, should be in office for six years. It should be competent to deal with matters which violate human rights in the African continent. Since the aim of the Committee is to protect human rights, it should be empowered to receive complaints direct from individuals or through their advocates. We would suggest that such individuals exhaust "all available domestic remedies" provided that no matters concerning violations of human rights should be delayed in the local courts for more than six months. If after six months the matter has not been disposed of by the local courts, the Committee will entertain the case. All matters communicated to the Committee will be in writing. No anonymous complaints will be admissible because it is likely that political malcontents might wish to embarrass their governments. On the other hand, since some African governments will be sensitive to even genuine complaints against it, the identity of such complainants should be disclosed only if the Committee in its wisdom, has proof that a genuine case would lie and that the attention of the State party which is alleged to have violated human rights needs to be drawn to the facts presented for its comments. Before this, the State so invited must have given prior recognition to accepting the jurisdiction of the Commission to receive such petitions ${ }^{15}$. The same case should not be examined by another international investigation or settlement body at the time it is subjudice ${ }^{\mathbf{1 6}}$.

\section{African Court of Human Rights}

The examination of an application as to its admissibility must involve scrutinising the facts to see if the subject matter of the application lies within the competence of the Commission. Having satisfied itself that it has the authority, the Commission should prepare the facts and investigate them with the cooperation of that country's Ministry of Justice or its Police Force. Next, the Commission should try to reconcile the parties to the dispute. Where it fails, the Committee should submit its findings to the African Court of Human Rights. We suggest that the procedure whereby in the Council of Europe, sub-commissions ${ }^{17}$ sem to play diversionary roles, should be eliminated.

The Court should have jurisdiction over all cases referred to it by the Commission. The Court's jurisdiction understandably, will not be absolute but subject to recognition by member states. The court should be made up of the Deputy Ministers of Justice of member States. Where a state is involved in the Court's proceeding, its affairs should be handled by its Solicitor-General, Advocate-General or Attorney-General. The case of the individual should be handled by an official from the O.A.U. College of Advocates. These should be lawyers whose names appear in the national registers of the various bar associations in the continent.

15 See, Article 25, Provisions of the European Convention on Human Rights, 1950.

16 Article 5, International Convenant on Civil and Political Rights.

17 This sub-commission, has ceased to exist in Europe by virtue of Article 2 of the Third Protocol amending Articles 29, 30 and 34 of the European Convention. 
Proceedings before the African Court of Human Rights should bear resemblance to those of the International Court of Justice at the Hague. The judgements of the African Court for Human Rights should be binding on African states and enforceable through the various Ministries of Justice. Decisions should be given wide publicity.

The need for the rule of law in Africa is urgent in view of the fact that between 1960 and 1979, there had been indiscriminate overthrow of constituted authority involving deaths or deprivation of human rights. The new goverments that took over power acted in panic, jailing people without due process of law ${ }^{18}$. No sooner they come to power than they suspend, amend or abrogate the constitution and other properly enacted laws. Then they rule by hastily prepared, ill-digested decrees.

On the other hand, the nature and essence of human rights pronouncements and practice by the ruling oligarchy often elicit popular revolt. In the class struggle that follows, human rights are violated and in some cases these are supposedly carried out in the name of law and order.

\section{Conclusion}

Africa must revert from the rule of force to the rule of law. Was it not the Whigs constitutional lawyer, A. V. Dicey, who laid down that the rule of law which forms a fundamental principle of the constitution excludes arbitrariness, of prerogative or even wide discretionary authority on the part of Government? In his brilliant lectures in Lagos, Nigeria in 1975, the eminent British jurist, Lord Denning repeatedly declared that freedom under the law was "the only guarantee to a just and democratic society". Freedom under the law creates the basis for the smooth functioning of democratic institutions.

It is under such conditions that man can exert himself in contributing his quota to the upliftment of himself and his fellow human beings. This is one reason why nations must strive to respect human rights and fundamental freedom.

18 In June, a revolutionary Military Government took over power in Ghana and after Kangaroo Court trial executed three former Heads of state. 